\title{
Historia jako dzieło wyobraźni w The Idea of History R.G. Collingwooda
}

DOI: http://dx.doi.org/10.12775/RF.2017.028

Na początek przywołajmy słowa doświadczonego historyka, które wydają się słuszne. Odnosząc się do starego sporu - w uproszczeniu - czy historia jest kunsztem czy metoda, sztuką czy nauka, Marc Bloch ironicznie zauważył, że dociekanie tego przywodzi mu na myśl dysputy scholastyczne:

Prawidłowe równanie matematyczne jest równie piękne, jak trafne zdanie. Ale każda dziedzina wiedzy ma własna, sobie tylko właściwą estetykę języka. Sprawy ludzkie [którymi zajmuje się dziejopisarstwo - I. S.] są z natury swojej zjawiskami bardzo delikatnymi, których większość nie daje się ująć w formuły matematyczne. Aby je poprawnie wyrazić, a w konsekwencji przeniknąć do głębi (czyż w ogóle możemy zrozumieć dobrze to, czego nie potrafimy wysłowić?), potrzeba wielkiej finezji języka, właściwych odcieni i tonu słów. Tam, gdzie niemożliwy jest ścisły rachunek, trzeba sugerować. Między odtwarzaniem rzeczywistości świata fizycznego a wyrażaniem rzeczywistości umysłu ludzkiego zachodzi w końcu taka sama różnica jak między pracą frezera a lutnika. Obaj pracują z dokładnością do milimetra; ale podczas gdy frezer posługuje się precyzyjnymi instrumentami mechanicznymi, lutnik kieruje się przede wszystkim wrażliwością ucha i palców. Nie byłoby dobrze ani gdyby frezer zadowolił się doświadczeniem lutnika, ani gdyby lutnik małpował frezera. Nikt chyba nie zaprzeczy, że podobnie jak czucie ręki, istnieje też czucie słów ${ }^{1}$.

1 M. Bloch, Pochwała historii czyli o zawodzie historyka, przeł. W. Jedlicka, oprac. H. Łaszkiewicz, przedmowa W. Kula, Wyd. Marek Derwiecki, Kęty 2009, s. 49-50. 
A zatem najwyraźniej według Marca Blocha ani wartości estetyczne decydujące o wielkim uroku, jaki ma dla nas nauka o dziejach, ani właściwe jej imaginacyjne wglądy, nie indukcja czy dedukcja, jako metoda postępowania, bynajmniej nie przeszkadzają w poznawaniu prawdy.

W szkicu tym będziemy krążyć wokół kilku fragmentów z The Idea of History (1946) Robina G. Collingwooda, książki uważanej w tradycji anglosaskiej za najważniejsze dzieło z zakresu historyki, poprzedzające Metahistory. The Historical Imagination in Nineteenth-Century Europe (1973) Haydena White'a. Tytuł wymieniał też sam twórca „poetyckiego" kierunku w badaniach relacji historycznych jako ważną pobudkę „fabularyzacyjnego" myślenia o historiografii ${ }^{2}$. Ceniąc Collingwooda przede wszystkim za pojęcie „,wyobraźni konstruktywnej”, dzięki której dziejopisarz - mimo najlepszych chęci zawsze koniec końców „narrator", ",artysta”, fantasta, tak się przynajmniej White' owi wydaje - z tego, co pierwotnie pozbawione sensu, ze "zbioru faktów”, wysnuwa „wiarygodną opowieść". Jednakże, wypłacając się z należnego długu, jednocześnie, postmodernistyczny teoretyk zaznaczał dystans w stosunku do inspiratora. Ten bowiem, przyznając, że dawne wieki ludzie zawsze oglądają z różnych perspektyw - narzucanych przez język, czasy oraz środowisko, naukowe zainteresowania oraz pojęciowe narzędzia jakiejś dyscypliny, myślowe albo uczuciowe skłonności osobiste i inne jeszcze tego rodzaju uwarunkowania - jako badacz rzymskiej Brytanii, ale także dziejów intelektualnych, w przeciwieństwie do dziedziczących po nim anglosaskich postmodernistów, imaginowanie łączył w jakiś sposób ze „zmysłem rzeczywistości”, by posłużyć się tu określeniem Isaiaha Berlina, i uważał, że minione wydarzenia jak najbardziej miały cechy dystynktywne, specyfikę, niepowtarzalny sens, co historyczna rekonstrukcja musi uszanować. Nie każda narracja byłaby stosowna w odniesieniu do pewnego zespołu faktów. Ponadto, zastrzegał, a mówimy o tym samym dziele, w którym wprowadzone zostało zagadnienie roli wyobraźni konstruującej w dziejopisarstwie, że uwrażliwienie na otwarty charakter przeszłości - gdyż każde pokolenie, stawiając jej własne pytania pisze ją w pewnym sensie na nowo - nie jest tym samym, co historyczny sceptycyzm i relatywizm³ ${ }^{3}$ Temu właśnie zastrzeżeniu chcemy w dalszym ciągu uważniej się przyjrzeć.

2 H. White, Poetyka pisarstwa historycznego, red. E. Domańska i M. Wilczyński, rozdz. Tekst historiograficzny jako artefakt literacki, przeł. M. Wilczyński, Universitas, Kraków 2000, s. 82-83.

3 "Collingwood nie dostrzegł jednak, że żaden zespół przypadkowo odnotowanych wydarzeń historycznych nie może sam z siebie ułożyć się w opowieść, w najlepszym razie może on dostarczyć historykowi elementów do jej budowy. Wydarzenia przekształcane są w opowieść przez przemilczenie lub podporządkowanie niektórych z nich innym, które z kolei wysuwają się na plan pierwszy poprzez nadanie im określonej charakterystyki, powtarzalność motywów, zmienność tonacji i punktu 
Odnotowawszy istnienie duchowej więzi między postmodernizmem a historyczną refleksją Collingwooda, nie zamierzamy śledzić tego wątku dalej. Autora The Idea of History, gdy podejmował on temat funkcji i możliwości historycznej wyobraźni, chcemy przedstawić $\mathrm{w}$ innym towarzystwie; wytwór angielskiego historyzmu zbliżając do niemieckich dziewiętnastowiecznych stanowisk Wilhelma Humboldta oraz Johanna G. Droysena. Oto nasza próbna hipoteza: choć lubił uważać, że do swoich pomysłów do ujęcia przedmiotu i metod historii doszedł sam na drodze praktyki - dzięki „doświadczeniu z pierwszej ręki”, nabytemu podczas badań archeologicznych rzymskiej Brytanii ${ }^{4}$, ale i wielu lat wykładania filozofii w Oksfordzie - rozumienia zagadnień historyki nauczyły go także książki.

Wskażmy podstawowe fakty: czytał z uwagą Hegla ${ }^{5}$ i swoje magnum opus, Speculum mentis or the Map of Knowledge z 1924 roku starannie wymodelował na ujęciu dziejowości ludzkiego umysłu w Fenomenologii ducha. Wielbił "historyzm absolutny" Crocego ${ }^{6}$, wielkiego przedstawiciela włoskiej linii Geistesgeschichte, orientującego się ku dokonaniom Hegla, Droysena, Wilhelma Diltheya, Georga Simmela. Znał prace Diltheya (o którym wypowiadał się z rzadkim u niego szacunkiem: „lonely and neglected genius"): Einleitung in die Geisteswissenschaften (1883), Aufbau der geschichtlichen Welt in den Geisteswissenschaften ${ }^{7}$ oraz pozostałe rozprawy składające się na tom VII Gesammelte Schriften, wydany przez Bernharda Groethuysena w 1927 roku. W wykładach z filozofii historii ${ }^{8}$ odnosił się do Die Probleme der Geschichtsphilosophie (1892) Simmela, obdarzonego cudowną zdolnością wglądu w naturę przeszłości,

widzenia, alternatywne strategie opisu i inne tym podobne zabiegi - krótko mówiąc, dzięki technikom, służącym zazwyczaj fabularyzacji powieści lub dramatu. Na przykład, żadne historyczne wydarzenie nie jest samo w sobie tragiczne; można je najwyżej tak postrzegać z pewnego punktu widzenia lub w obrębie określonego kontekstu wyznaczonego przez ustrukturyzowany szereg wydarzeń, w ramach którego zajmuje ono uprzywilejowaną pozycję". Za: H. White, Poetyka pisarstwa historycznego..., op. cit., s. 83.

4 R. G. Collingwood, Autobiografia. Z dziejów mojego myślenia, przeł. I. Szyroka, Nomos, Kraków 2013, s. 80-81.

5 Liczne komentarze Collingwooda w rękopisie do heglowskiej filozofii historii przechowuje Bodleain Library.

6 Dodajmy, że wiele uczynił dla przyswojenia tego autora angielskiemu filozoficznemu środowisku jako tłumacz, życzliwy komentator i recenzent wydawniczy.

7 Polski przekład, autorstwa E. Paczkowskiej-Łagowskiej, Budowa świata historycznego w naukach humanistycznych, obejmujący też rozprawy: Aufbau der geschichtlichen Welt..., Plan der Fortsetzung zum "Aufbau der geschichtlichen Welt in den Geisteswissenschaften", Zusätze zum "Aufbau der geschichtlichen Welt", z tomu VII Gesammelte Schriften, opublikowało w 2004 roku wydawnictwo Słowo obraz/terytoria.

8 Włączonych przez wydawcę T. M. Knoxa do The Idea of History. 
ale - w jego odczuciu - zbyt wielkiego impresjonisty ${ }^{9}$, oraz do Grundriss der Historik (1852) Droysena; w tym ostatnim przypadku - co tu raczej dziwi - krytycznie, zdawkowo. Badacze intelektualnej biografii Collingwooda wśród jego lektur z lat trzydziestych, z okresu prac nad historią jako formą myślenia, wymieniają poza tym m.in. kompendia Eduarda Fuetera, Geschichte der neueren Historiographie (1911) oraz Zur Theorie und Methodik der Geschichte (1910) Eduarda Meyera.

Pisarstwu Collingwooda przewodziła wola doprowadzenia do pojednania filozofii $\mathrm{z}$ historią; $\mathrm{w}$ tej sprawie deklaracje złożone osobiście w Autobiografii całkowicie pokrywają się z wrażeniami, jakie ma czytelnik jego prac. Warunków dla zbliżenia ich stanowisk poszukiwał w pojęciu historycznego człowieczeństwa, wieloznacznym, bogatym w filozoficzne konsekwencje, kształtującym się na gruncie idealistycznej antropologii oraz teorii rzeczywistości. Powyższy zestaw reprezentatywnych nazwisk przypomina nam od razu o zróżnicowaniu postaw w ramach idealizmu i skomplikowanych wzajemnych relacjach konkretnych jego przejawów, czego jednak nie możemy teraz referować. Pragniemy tylko zwrócić uwagę na występujący tu wspólny mianownik. Pochodzi on z Kantowskiej tradycji myślenia krytycznego, poddanego wszakże historyzacji: podejrzenie, że za sensowna, uporządkowaną strukturę zjawisk - czyli za nasze poznawcze panowanie nad danym nam światem - odpowiadają ogólne pojęcia świadomości, uprzedzając, dodajmy: zawsze pozostającej pewnym „dziejowym skutkiem”.

Domysł ten po raz pierwszy, zdaje się, wypowiedział Droysen:

[...] dostrzegamy wokół nas ciągłą dynamikę, ciągłą zmianę. Ale wyróżniamy pewne zjawiska, w których to, co czasowe, wycofuje się, w których zjawia się ono jedynie chwilowo, aby osunąć się w siebie samo. Wyróżniamy zjawiska, które stale się powtarzaja ale w których nieskończone następstwo czasu daje się rozłożyć na równo powtarzające się kręgi (okresy), w taki mianowicie sposób, że taka konfiguracja zjawia się nie jako ,jedna co do liczby, lecz jako jedna co do rodzaju". W takich zjawiskach duch ujmuje to, co stałe, to, w czym dokonuje się ruch, to, co $w$ zmianie pozostaje takie samo: regułę, prawo, tworzywo, wypełnienie przestrzeni itd. Zatem formy się tu powtarzają a jednostajny charakter ich periodycznego powrotu obniża rangę czasowego aspektu ich dynamiki do momentu drugorzędnego, wprawdzie nie z uwagi na ich byt, lecz dla naszego ujmowania i rozumienia. Tak oto nasze ogólne przedstawienie przestrzeni uzyskuje swoją dyskretną treść, a stanowi ją to, co określamy mianem przyrody.

9 „Simmel's was a lively and versatile mind, gifted with a good deal of originality and penetration, but defective in solid thought; and his work on history is full of good observations but of little value as a systematic study of the problem" w: The Idea of History, op. cit., s. 170. 
W innych zjawiskach duch nasz uwydatnia to, co $w$ tym samym $i$ w takim samym jest zmienne (das im Gleichen Wechselnde). Dostrzega bowiem, że ruch tworzy tutaj wciąż nowe formy. Formacje tak nowe i tak silnie warunkujące, że materia, w której się one zjawiają sama jawi się jako moment drugorzędny. Każda z nowych form jest czymś indywidualnie innym, a mianowicie $\mathrm{w}$ tym sensie, że wchodząc $\mathrm{w}$ szereg swych poprzedników, jest przezeń uwarunkowana, z nich powstając, obejmuje je sobą idealnie - $\mathrm{z}$ nich powstała i idealnie je w sobie zawiera i przechowuje. Jest to pewna ciągłość, w której wszystko, co wcześniejsze, zyskuje swoją kontynuację, uzupełnienie, poszerzenie [...] w tym, co późniejsze. Wszystko zaś, co późniejsze, prezentuje się jako wynik, spełnienie, wzmocnienie tego, co wcześniejsze. Nie jest to ciągłość stale powracającego koła, pewnego powtarzającego się okresu, lecz ciągłość nieskończonego szeregu, tak, iż w każdym nowym elemencie kiełkuje i wyrasta już następny element. $W$ każdym $z$ nich sumuje się więc ideowo cały szereg przeżytych form, a każda z tych form jawi się jako moment, jako aktualny składnik w stającej się sumie. W tym ciągłym następowaniu po sobie, w owej wzmagającej się w sobie samej ciągłości, ogólne przedstawienie czasu uzyskuje swoją dyskretną treść, którą określamy mianem historii $(\text { Geschichte })^{10}$.

W ten sposób dziedziny przyrody i historii zostały przez Droysena zidentyfikowane jako należące do tak zwanych naoczności apriorycznych. Są dla niego najbardziej ogólnymi przedstawieniami czy kategoriami w kantowskim znaczeniu słowa. Źródłem ich jest świadomość włączona w przebieg historii. A stąd:

Badanie historyczne zakłada refleksję nad tym, że również treść naszego Ja jest pewnym zapośredniczonym, dokonanym, historycznym rezultatem. [...] nasza wiedza jest czymś przejętym, odziedziczonym - nasza, a jakby naszą nie była. Daleko jeszcze do tego, by poczuć się przy niej swobodnie i swobodnie nią dysponować. Z totalności tego, co w ten sposób posiadamy, za sprawą naszego odczuwania (Empfindung) tych naszych treści i naszego odczuwania siebie (Selbstempfindung) z wiedzy wyłania się nam [...] nowe przedstawienie całości, części, pojedynczego momentu. Powstaje ono w nas w sposób niedowolny, jest obecne jako coś faktycznego. Ale czy rzeczywiście jest tak, jak nam ono pokazuje? By uzyskać pewność, musimy się zastanowić nad jego powstaniem; musimy przebadać jego zapośredniczenie; musimy go dowieść, rozjaśnić, wykazać $^{11}$.

Refleksja nad historycznością umysłu i jego pojęć, a potem, konsekwentnie, nad możliwością i potrzebą objęcia "hermeneutyczną" pro-

10 J. G. Droysen, Zarys historyki, przeł. i oprac. M. Bonecki, J. Duraj, Oficyna Wydawnicza Epigram, Bydgoszcz 2012, s. 83-84.

11 Ibidem, s. 25. 
cedurą już nie wyłącznie studium tekstów, lecz w ogóle naukowych badań nad kulturowym światem człowieka, pod różnymi nazwami oraz w różnym zakresie zainicjowana na gruncie idealizmu bądź neoidealizmu, stanowiąca znak szczególny myślicieli, których wcześniej wymieniliśmy, to nośne tło filozofowania o historii Collingwooda. Pomysł w pierwszej chwili jawiący się jako co najmniej nieintuicyjny - by akty imaginacji uczynić gwarantem prawdziwości dziejopisarstwa - należał również do tamtego intelektualnego kręgu. Dwuznaczność, zauważalna w The Idea of History, wyrażająca się uznaniem przypadkowości historycznej egzystencji, z czego wynika w sposób naturalny poznawczy relatywizm, przy jednoczesnej wierze, że tylko nauka o dziejach, a nie filozofia (sic!) umożliwi nam rozstrzygnięcie istotnych pytań o moralność, politykę czy układanie międzyludzkich relacji, w oczach White’a przedstawiająca się jako przykre i w gruncie rzeczy niezrozumiałe ograniczenie poglądu, ma źródło w dwuznacznym historyzmie tamtego środowiska. Rozpoznaniu, że człowiek wraz ze swoim rozumem oraz etyką „egzystuje w horyzoncie dziejów", z czego wynika jego niekompletny ogląd wszelkich spraw, nie towarzyszył tam entuzjazm z powodu wyzwolenia od faktu ku literaturze i subiektywności punktu widzenia w dziejopisarstwie. Dostrzegamy raczej zatroskanie o „obiektywną miarę i kontrolę" dla naszych subiektywnych ujęć przeszłości - „dostępnej jedynie poprzez cudze ujęcia lub fragmenty tego, co niegdyś istniało" bez czego nie istnieje uzasadnienie przedstawienia oraz pogłębiona wy$k^{k ł a d n i a^{12}}$. A szczegółowy problem znaczenia wyobraźni w pracy dziejopisarza został postawiony w kontekście bardziej ogólnego, poważnego, pytania o doniosłość historii dla nas w tej właśnie sytuacji. Tak jest też u Collingwooda.

Postarajmy się jednak odtworzyć, jaki dokładnie kształt nadał zagadnieniu wyobraźni angielski uczony. W paragrafie 2. Epilegomena ${ }^{13}$, zatytułowanym The Historical Imagination, zaczyna od krytyki, jak to nazywa, „zdroworozsądkowej teorii dziejopisarstwa”, zakładającej takie pojęcia, jak pamięć i autorytet, aby za ich pomocą wyjaśniać, dlaczego historycy potrafia mimo wszystko, przedstawiać swój przedmiot zgodnie $\mathrm{z}$ prawdą. W skrócie głosi ona: wiedza o przeszłym stanie rzeczy będzie możliwa, jeśli istnieją czytelne dla nas świadectwa, pozostawione przez ludzi pamiętających dawne wydarzenia. W nich, niczym w świętych księgach, zawiera się nasza prawda: dana z góry i oczekująca na wydobycie. W przypadku dzieł historycznych musimy zatem dążyć do zgodności tez $\mathrm{w}$ nich zawartych $\mathrm{z}$ twierdzeniami źródeł. Przejęty taką zdroworozsądkową teorią badacz, mimo iż w praktyce, jak z łatwością obserwujemy, co i raz w stosunku do autorytetów odstępuje od wia-

12 Patrz: J. G. Droysen, Zarys historyki, op. cit., s. 95.

13 W The Idea of History, op. cit. 
ry - gdy sięga wobec materiału po krytyczne procedury, odrzuca część dokumentów, porządkuje zweryfikowane źródła, interpretuje czy uzupełnia - nie wie sam, co czyni; przedstawia siebie jedynie jako czciciela albo depozytariusza przekazu.

Trudno powiedzieć, którzy to historycy byli wówczas jeszcze tak nieokrzesani i Collingwood też nie udziela w tej sprawie informacji. Zamiast tego przystępuje do odparcia kacerstwa. Nerwem całej argumentacji będzie autonomia myślenia. $\mathrm{W}$ formie najmniej skomplikowanej dostrzegamy ją w decyzjach, jakie podejmuje badacz życia z odległej przeszłości, gdy porządkuje fakty zgodnie z pewnym zamysłem. Postępuje on w gruncie rzeczy tak, jak i każdy malarz-pejzażysta, który odwzorowując naturalne barwy i kształty, umieszcza na płótnie tylko to, co dla uzyskania efektu naturalnej jedności uznał za potrzebne. Za dzieło, to oczywiste, odpowiada malarz, nie natura. Lecz autonomia nie wyczerpuje się w selekcji materiału. Źródła nie mówią wszystkiego i historyk musi zwykle opowiedzieć również niewiadomą z przekazu dokumentów. Co trzeba wiedzieć, rekonstruuje, ze świadectw, wnioskując stosownie do „własnych kryteriów, metodologii oraz pojęcia adekwatności"14. Źródła bywają niewiarygodne, gdyż przekaz, jaki zawierają powstawał przecież w różnym celu: dla współczesności, dla następnych pokoleń, aby uczcić, uczyć, bawić lub jako środek pewnej polityki, stworzyli go przyjaciele lub wrogowie; nie ma potrzeby wymieniać dalej. Przekaz powstawał też $\mathrm{w}$ określonym umysłowym horyzoncie: pozostawili go ludzie, którzy rozumieli, odczuwali czy umieli sobie wyobrazić tyle, ile było możliwe w ich sytuacji. Historyk, jeśli chce przeniknąć do głębi zespół wydarzeń, postępuje więc jak detektyw w sprawie kryminalnej lub sędzia śledczy. Nie zadowala go to, co Liwiusz czy Swetoniusz wyraźnie powiedzieli $\mathrm{w}$ jakimś tekście. I tak samo nie bierze za dobrą monetę ustaleń, jakie poczynili inni, badający temat przed nim. Za pomocą krytycznej procedury, zadając im podstępne i niespodziewane pytania, egzaminuje kompetencje i motywację swoich „źródeł narracyjnych", wskutek czego znajduje zazwyczaj potrzebę wezwania nowych świadków oraz komentatorów. Ilustrując powyższe, Collingwood szkicuje zabawną opowiastkę rodem z kroniki kryminalnej angielskiej prowincji, gdzie w roli alter ego krytycznego dziejopisarza pojawiają się, jednocześnie, sumienny wiejski konstabl i błyskotliwy inspektor Scotland Yardu, którzy wyjaśniając zagadkę śmierci pewnego drobnego szantażysty, łączą swoje detektywistyczne doświadczenia i podejścia ${ }^{15}$ w zakresie ustalenia faktów i stwierdzenia prawdomówności świadków (konstabl), ale też dostarczenia całościowej interpretacji zdarzenia (inspektor Scotland Yardu), będącej czymś różnym w stosunku do jego ob-

14 R. G. Collingwood, The Idea of History, op. cit., s. 237.

15 Ibidem, w paragrafie 3 pt. Historical Evidence, s. 266-268. 
razu z relacji tych ostatnich. Różnym, ponieważ dopiero z inteligentnych pytań śledczych wyłania się właściwe znaczenie zdarzenia.

Morał z tego wszystkiego wyciąga Collingwood następujący: historyk nie ma autorytetów poza własnym naukowym sumieniem. I tak samo jego sąd zachowuje niezawisłość wobec zasady pamięci: badacz umie bowiem odkryć nie tylko to, co z jakichś powodów zostało kiedyś zapomniane, ale nawet rzeczy, o istnieniu których nigdy nie napomknął żaden świadek w przekazie tradycji. Co nie jest znowu ani magia, ani mistyka, lecz zwyczajnie wynika z włączenia do naszych źródeł historycznych również tak zwanych „świadectw mimowolnych"16, czyli wszelkich pozostałości przeszłego życia w rodzaju pomników, inskrypcji, medali, budowli, umów handlowych, gazet i wielu innych. Jak mówił Droysen: „sztuka heurystyki polega na poszerzaniu materiału historycznego”. A także: „wszelka historyczna, jak i wszelka przydatna wiedza - filologiczna czy rzeczowa - stanowi tu naukę pomocniczą"17.

Wspomnieliśmy Droysena. Trzeba to jednak powiedzieć: Collingwood, który w odniesieniu do dziejopisarstwa pragnął skromnie stać się nowym Baconem ${ }^{18}$ i uważał, zdaje się, obserwacje Droysena za trywial$\mathrm{ne}^{19}$, nie przekonuje, gdy z wielką pewnością siebie ogłasza dziewiętnastowiecznej historyce jako przewrót własną filozofię historii. Gdyż ani treść tej ostatniej, ani tym bardziej przedstawienie tam szczegółowych zagadnień z metodyki, nie ustanawia w stosunku do Zarysu historyki żadnego nowego początku. Zwłaszcza, jeśli mamy w pamięci umiejętność Droysena z jednej strony swobodnego różnicowania historycznego materiału, jego form prezentacji i dopuszczalnych ujęć, z drugiej zaś systematyzacji typów procedur interpretacyjnych oraz krytycznych w historiografii. Albo, wyniesioną z naukowej praktyki, samowiedzę tamtego w zakresie możliwych do uzyskania rezultatów badawczych, którą konsekwentnie starał się już wyłożyć w filozoficznych pojęciach ${ }^{20}$. Czytamy u niego:

Nawet najdoskonalsze źródła dają [...], by tak rzec, jedynie spolaryzowane światło". [...] Krytyka nie poszukuje autentycznego faktu historycznego. Każdy tzw. fakt historyczny, abstrahując od współoddziałujących środków, kontekstów, warunków, celów, jest kompleksem sprzyjających

16 Określenie M. Blocha. Patrz: Pochwała historii..., op. cit., s. 76.

17 J. G. Droysen, Zarys historyki, op. cit., s. 28.

18 Patrz: R. G. Collingwood, Autobiografia. Z dziejów mojego myślenia, Nomos, Kraków 2013, rozdz. IX-XI: Podwaliny przyszłości, Historia jako samowiedza umystu, Rzymska Brytania.

19 Patrz: The Idea of History, op. cit., s. 165-166.

$20 \mathrm{Na}$ co, za J. Rüsenem (Begriffene Geschichte. Genesis und Begründung der Geschichtstheorie J.G. Droysen, Schöningh, Paderborn 1969), zwracali ostatnio uwage polscy tłumacze Zarysu historyki, M. Bonecki i J. Duraj. 
czy niesprzyjających aktów woli [...], jakie przeminęły wraz z teraźniejszością do której należały. Ujawniają się one [...] albo w pozostałościach po tym, co wówczas uformowano czy dokonano, albo w ujęciach i wspomnieniach. Rezultatem krytyki nie jest autentyczny fakt historyczny, lecz takie opracowanie materiału, które umożliwia jego stosunkowo pewne i poprawne ujęcie [...] Tylko pozornie przemawiają tu same fakty, tylko i wyłącznie one, obiektywnie. Tymczasem bez narratora, który pozwala im mówić, byłyby nieme [...] Że historia nie jest niczym zewnętrznym i realistycznym, lecz istnieje jako tak a tak przekazana, zbadana i uświadomiona - musi stanowić dla nas punkt wyjścia, jeśli chcemy zaprzestać naturalizowania historii [...] Materiałem naszych badań nie jest po prostu przeszłość. Częściowo mamy do czynienia z pozostałością po niej, a po części z rozmaitymi ujęciami tego, co minione. Pozostałość, o której mowa, jest pozostałością jedynie $\mathrm{z}$ historycznego punktu widzenia, $\mathrm{w}$ istocie znajduje się pośrodku teraźniejszości. [...] niekiedy, przekształcone, nadal pozostaje w praktycznym użyciu. Czasem zaś, zmienione nie do poznania, w pełni zatopione jest w teraźniejszym bycie ${ }^{21}$.

Poza sens tych myśli, przez Droysena ujętych w lapidarnym skrócie, Collingwood nie wykroczył. Parafrazując uwagę Pascala, w tym wypadku jednak „stare idee w nowym układzie nie stworzyły innej treści”.

Zatem niemiecki filozofujący metodolog i Collingwood podobnie konstatują niezależność historycznej myśli w stosunku do źródeł i faktów, co, znów podobnie, nasuwa im jako temat kolejny funkcję wyobraźni w dziejopisarstwie. Obaj zastrzegają też od razu, że pojęcie to przede wszystkim trzeba oddzielić od zwykłego zmyślania i fikcji. Zaznaczmy na marginesie, że w ten sposób włączają się w długa niemiecką dyskusję na temat kompetencji poszczególnych władz poznawczych, no i, co tu najważniejsze, różnicy pomiędzy wyobraźnią a pospolitą fantazją. Zaczyna się ona w teorii sztuki jeszcze w XVIII wieku u Szwajcarów, Bodmera i Breitingera, a przez klasykę, Herdera, prowadzi do wydobycia nowego znaczenia słowa u Humboldta ${ }^{22}$ : teraz wyobraźnia staje się organem, za pomocą którego artysta obiektywnie ujmuje ideę natury, krytyk zaś, równie obiektywnie, ideę przedstawioną w dziele. To rozpoznanie, że w dziedzinie sztuki imaginacja pewnością rezultatów dorównuje rozumowaniu na polu filozofii, będzie dla zestawianych tu autorów ważne.

Dalej zaś, podkreślają oni zgodnie, że - inaczej niż przedstawia się to w eseistyce Macaulaya - wyobraźnia w historii nie jest zwykłym ornamentem, który dziełu przydaje wartości estetycznej, potęguje siłę jego oddziaływania.

21 J. G. Droysen, Zarys historyki, op. cit., ss. 27, 28, 31, 51, 93.

22 Po polsku została ona zrelacjonowana przez K. Sauerlanda: Od "wyobraźni" do "przeżycia", czyli droga do Diltheya, w jego: Od Diltheya do Adorna. Studia z estetyki niemieckiej, PIW, Warszawa 1986. 
Droysen wyraża to tak:

Dokonujemy podziałów i rozróżnień ze świadomościa, że takie postępowanie stanowi jedynie środek pomocniczy dla naszego intelektu, który docieka drogą rekonstrukcji, podczas gdy inne czynności naszej duszy natychmiast i bezpośrednio oddają odczuwane totalności (Totalitäten) ${ }^{23}$. [...] Wszelka empiria polega na specyficznej energii organów zmysłowych. Przez ich podrażnienie duch uzyskuje nie odbicia, lecz znaki rzeczy zewnętrznych, które owe pobudzenie spowodowały. W ten sposób rozwija on systemy znaków [...], wciąż korygowany, rozszerzany i wzbogacany dzięki postrzeganiu świat przedstawień, w których duch posiada świat zewnętrzny w takiej mierze, w jakiej może go posiadać, w jakiej musi go mieć, ażeby go ująć i opanować poprzez wiedzę, wolę i kształtowanie. [...] Na dane badania historycznego nie składa się to, co przeszłe, skoro już przeminęło, lecz raczej to, co z niego tu i teraz jeszcze pozostało; mogą to być wspomnienia lub pozostałości tego, co było [...] Każdy punkt w tej teraźniejszości jest czymś, co już się dokonało. [...] jego przeszłość tkwi w nim jako coś jedynie idealnego (ideell). Atoli tylko idealnie, jako wyblakłe ślady, utajone blaski; nieuświadomione byłyby tak, jak gdyby ich nie było. Wnikliwy ogląd, badawcze spojrzenie jest w stanie je rozbudzić, na nowo ożywić, pozwolić im raz jeszcze rozbłysnąć pośród ciemnej pustki przeszłości ${ }^{24}$. [...] Siłą spojrzenia i wiedzy o rzeczach przeszłych, duch wszechstronnie rozświetla swą teraźniejszośćc ${ }^{25}$. [...] Rozumienie jest zarówno syntetyczne, jak i analityczne, jest zarówno indukcją jak i dedukcją ${ }^{26}$.

A polemicznie o wyjaśnianiu w historii mówi, że tam, "gdzie idzie o uwarunkowania naturalne, o statystycznie określone stany rzeczy" prace nauk ścisłych „przyjmowane są z wdzięcznością”. Nie wyjaśnimy jednak „pięknego pomnika adoranta”, skupiając się na „spiżu, z którego został odlany, glinie, z której sporządzono formę, ogniu, za pomocą którego roztopiono metal”. W tym przypadku „potrzeba również wyobrażenia wizerunku, który miał się tam znaleźć; a tkwił w duszy artysty, zanim powstało dzieło. [...] Potrzeba [...] celu, ze względu na który rzeźba miała powstać" 27 .

Jednym słowem: w pracy historycznej, poza wiedza, czerpaną również z innych dyscyplin szczegółowych, absolutnie nieodzowna jest pewna szczególna kształtująa naoczność. Zdolność przedstawiania sobie tego, co było, i czego badacz osobiście nie przeżył wcześniej, czyli wy-

23 Ibidem, s. 73.

24 Ibidem, s. 20.

25 Ibidem, s. 21.

26 Ibidem, s. 22.

27 Dyskutując z poglądem Buckle’a na „naukowość” historii. Ibidem, s. 72. 
obraźnia. Ale jak właściwie należy rozumieć władzę, o którą tu chodzi? Czy byłaby nią po prostu tak zwana wyobraźnia empiryczna?

Dwie uwagi Droysena wydają się w tym kontekście szczególnie interesujące: to sama „pragmatyczna natura” przedmiotu historii kreśli już uczonemu „hipotetyczną linię"28; zadaniem dziejopisarza jest potwierdzić ją oraz: „ciekawe byłoby prześledzić immanentny powód [podkreśl. I. S.], z którego to właśnie historii jako jedynej spośród nauk przypadło dwuznaczne szczęście, mianowicie że ma być ona jeszcze kunsztem”29. Powrócimy do tego.

Oddajmy teraz głos Collingwoodowi. Bez wyobraźni w kantowskim sensie słowa nie istniałoby dla nas to, co nazywamy popularnie otaczającym nas światem, stwierdza angielski uczony. Z kolei bez wyobraźni jako formy apriorycznej nie do pomyślenia byłaby jakakolwiek rekonstrukcja w dziejopisarstwie. W tym ostatnim pełni ona „funkcję strukturalną" ${ }^{30}$. W ciągu dalszym, wyłuszczając znaczenie pojęcia, dodaje, że sama w sobie imaginacja nie jest ani rzeczywista, ani nierzeczywista. Kreśli też dla niej paralelę z wyobraźnią działającą w sztuce: w ich wytworach od pierwszej chwili dostrzegamy „konieczność wewnętrzną". I, rzec by można, obie odpowiadają za powstające w rezultacie dzieło, tam artystyczne, tu historyczne, od początku do końca. Z czego wynika, że dla Collingwooda owa imaginacja aprioryczna ustanawia nawet tak zwane historyczne fakty.

Czy jednak nie staraliśmy się wcześniej, uwypuklając właściwy mu zmysł rzeczywistości, przeciwstawić się zawłaszczaniu Collingwooda przez White'owski postmodernistyczny konstruktywizm? Trudność, na jaką przed chwilą natrafiliśmy, jest pozorna. Znika, jeśli rzecz wziąć nieliteralnie i w kontekście.

Zacznijmy od ostatniej kwestii. Kontekst tworzą oryginalne refleksje Kanta o znaczeniu wyobraźni - wszelako nie w sensie "psychologicznym”, „zdolności duszy”, niższej zmysłowej władzy poznawczej, lecz jako warunkującej tamte zdolności apriorycznej - dla wszelkiego możliwego poznania. Rezultaty namysłu nad tym zagadnieniem, jeśli porównać pierwsze i drugie wydanie Krytyki czystego rozumu, różnią się istotnie (i również Kant niejednokrotnie waha się pomiędzy rozumieniem wyobraźni empirycznym a transcendentalnym), co inspirowało do komentarzy, których nie brakuje ${ }^{31}$. Heidegger, podążając za Fichtego

28 Ibidem, s. 96.

29 Ibidem, s. 92.

30 R. G. Collingwood, The Idea of History, op. cit., s. 241.

31 Por. H. Blocker, Kant's Theory of the Relation of Imagination and Understanding in Aesthetic Judgement of Taste, "The British Journal of Aesthetics", vol. 1, 1965; E. M. Wolff, Etude du role de l'imagination dans la connaissance chez Kant, Carcassone 1943; R. Daval, La métaphysique de Kant, Paris 1950; M. Heidegger, Kant a problem metafizyki, przeł. i przedmową opatrzył B. Baran, Warszawa 1989; W. Juszczak, 
i Schellinga rozumieniem Kantowskiego poglądu na wyobraźnię, uniwersalizuje rolę tej ostatniej; nie zawęża się ona wyłącznie do obszaru sztuki, jej dziedziną tak samo staje się „przyroda”. Zatrzymamy się przy zarysowanej w Kant a problem metafizyki interpretacji stanowiska klasyka, gdyż rzuca ona sporo światła na w pierwszej chwili jawiące się jako osobliwe przekonanie Collingwooda o ugruntowaniu prawdy historycznej $\mathrm{w}$ apriorycznej imaginacji.

Znaczenie szczególne Heidegger przydaje wydaniu pierwszemu Krytyki. Dokonując twórczej rekonstrukcji tego dzieła, uwidaczniając to, co w „wypowiedzianych tezach nauka Kantowska stawia przed nami jako jeszcze nie wypowiedziane" ${ }^{\prime 2}$, w pojęciu wyobraźni transcendentalnej znajduje sens, który zdumiewająco antycypuje jego własną egzystencjalną analitykę jestestwa. „Przewrót kopernikański”, mówi, nie polegał na dostarczeniu "teorii doświadczenia" czy "teorii nauk pozytywnych", jak fałszywie przedstawiają to neokantyści. Zasadnicze Kantowskie pytanie nie zostało postawione na ontycznym gruncie teorii poznania, lecz na planie metafizycznym: ontologii fundamentalnej jako warunku możliwości tego, co ontyczne i metafizyki, która w różnych formach trwale przypisana jest „naturze” człowieka. Nie brzmi ono: czym jest prawda matematyczno-fizykalna? Lecz: czym jest prawdziwość transcendentalna, która poprzedza wszelką empiryczną prawdę i umożliwia tę ostatnią? ${ }^{33}$ Innymi słowy: dlaczego tak zwany empiryczny "podmiot poznający" w ogóle uchwytuje w poznaniu szeroko rozumiany "byt"? A w języku Heideggera, który przedstawiciela Oświecenia uwspółcześnia: na czym polega możliwość uprzedniego rozumienia bycia wszelkiego „bytu”? I otóż: możliwość tę Kant odsłaniał, wnikając w architektonikę podmiotowości transcendentalnej, czyli w strukturę i funkcje czystej naoczności oraz czystego myślenia. Na tej najbardziej pierwotnej płaszczyźnie, poza którą krytyczne badanie dalej nie byłoby już zdolne wykroczyć, mamy do czynienia z rozmaitego typu, ale powiązanymi ze soba, czynnościami syntezy: „syntezą ujmowania”, „syntezą odtwarzania”, apercepcją transcendentalną jako „syntetycznym wiązaniem ze sobą tego, co różnorodne w jednym poznaniu"34. Bliższe przyjrzenie się wszystkim tym modi syntetyzowania odsłania nam, zdaniem Heideggera, samorzutny i receptywny jednocześnie charakter transcendentalnej podmiotowości na różnych jej poziomach. Na każdym z nich bowiem antycypowane są na sposób wyobrażeniowy jedności: empiryczne dane

Mroczne źródło poznania, w: Wędrówka do źródet, Gdańsk 2009; J. P. Hudzik, Koncepcja wyobraźni w filozofii Kanta, „Sztuka i Filozofia”, 1994, nr 8.

32 M. Heidegger, Kant a problem metafizyki, op. cit., s. 225.

33 Ibidem, s. 24, op. cit.

34 I. Kant, Transcendentalna dedukcja czystych pojęć intelektu (wyd. A), w: idem, Krytyka czystego rozumu, przeł. R. Ingarden, BKF, PWN, Warszawa 1957, s. 202-213. 
naoczne, pojęcia. Czysty ogląd naoczny jako czasowość „pre-formuje” i kształtuje sam to, co każdorazowo zdolny jest odbierać. Z kolei intelekt posługuje się wytworzonymi przez transcendentalną wyobraźnię schematami - kompleksem reguł konstruowania obrazów określonego typu, które odpowiadają pojęciom. Stąd powiada Kant:

Posiadamy [...] czystą wyobraźnię jako podstawową zdolność duszy ludzkiej, znajdująca się a priori u podstaw wszelkiego poznania. Za jej pośrednictwem wiążemy różnorodność naoczności z jednej strony ze soba, a z drugiej z warunkiem koniecznej jedności czystej apercepcji. Oba najdalsze końce, mianowicie zmysłowość i intelekt, muszą koniecznie pozostawać ze sobą w związku za pośrednictwem tej transcendentalnej funkcji wyobraźni; w przeciwnym bowiem wypadku dostarczałyby one wprawdzie zjawisk, ale nie przedmiotów empirycznego poznania, a więc nie dawałyby żadnego doświadczenia ${ }^{35}$.

Radykalizm Kantowskiej myśli, przed rezultatem którego ona sama ostatecznie się cofa ${ }^{36}$, polega na tym, uważa Heidegger, że dostrzegła $\mathrm{w}$ apriorycznej imaginacji nie tylko zdolność poznawcza, ale po prostu sposób egzystowania transcendentalnego Ja (dostrzegła w niej egzystencjał). Wejrzała zatem $\mathrm{w}$ istotowe ukonstytuowanie człowieka jako „zakorzenione" w czystej wyobraźni - projektowaniu z góry horyzontu, w którym empirycznemu poznającemu ja przedstawiają się wszelki sens i byt $\mathrm{w}$ świecie. Uprzednią podstawą dla naszego znajdowania się zawsze już w relacji ze "światem” oraz adekwatnych w stosunku do przedmiotu poznania pojęć byłaby wyobraźnia projektująca. Wyobraźnia rozumiana jako nasza ludzka kondycja.

Czy wszakże wolno nam uznać powyższe, tak uwspółcześnione, odczytanie klasyka za miarodajne? Kierunek, w jakim podążyli Humboldt i Droysen, którzy w ramach tematu historycznego człowieczeństwa również uczynili użytek z nauki Kanta o wyobraźni, przemawia jednak za prawomocnością tej interpretacji.

Pierwszy był tu - Droysen to podkreślał - Humboldt:

W badaniach Wilhelma von Humboldta odkryłem idee, które, moim zdaniem, przetarły szlak; Humboldt wydał mi się Baconem nauk humanistycznych. [...] Jego myśli i badania oraz wyniesione z aktywnego życia doświadczenie zaowocowały światopoglądem, którego punktem ciężkości było silne i dojrzałe poczucie tego, co etyczne. Podążając za praktycznymi i idealnymi tworami rodzaju ludzkiego, tj. językami, rozpoznał on ich "duchowo-zmysłową naturę" oraz moc ekspresji, twórczą i żywą w dawaniu i odczuwaniu - obu momentach, w których świat moralny,

35 Ibidem, A124, s. 229-230.

${ }^{36}$ W drugim wydaniu Krytyki, gdzie wyobraźnia, choć wciąż niezbędna, zostaje jednak „odsunięta na bok" i podporządkowana intelektowi. 
w coraz to nowych polaryzacjach, coraz to nowe prądy elektryczne wyzwalając, twórczo się porusza i w tym ruchu tworzy. Wychodząc od tych przemyśleń, zdało mi się możliwe głębsze wniknięcie w kwestię naszej nauki, uzasadnienie jej procedury i zadań, a dzięki poznaniu jej natury także doprowadzenie jej do ostatecznej postaci ${ }^{37}$.

Przypomnijmy zatem. Dziejopisarz - powiadał Humboldt - w swych studiach ma zawsze na uwadze to, co konieczne: samą prawdę faktów ${ }^{38}$. Jego powołaniem jest „budzić i ożywiać zmysł rzeczywistości”, co czyni ukazując nam przeszłe życie jako splot wewnętrznej konieczności oraz kontyngencji, zależności wszelkiego istnienia od „przed” i „teraz”, przemijalności wszystkiego, wolności ludzkiego umysłu. W tym celu z zaistniałych wydarzeń „zdejmuje formę”, w której przejawia się ich wewnętrzny związek, i w dziele odrysowuje „prawdziwy kształt” historii; jej „,idee”. Poprzez zmysłową skorupę zjawisk - mieniąca się odcieniami, rozmaitością organizacji, wysoce skomplikowaną i samą w sobie interesującą - spojrzenie dziejopisa zwraca się ku ich idealnemu źródłu, jakim jest wiecznie stające się, twórcze i refleksyjne „Ja ludzkości”. „Idea nieskończona" ze względu na nieprzebrane bogactwo ukrytych w niej możliwych treści.

Spotykamy się tu niewątpliwie z nietrywialnym pojęciem historii. Przejmie je też Droysen. Nie jest to już wiedza o rzeczach przeszłych. W stopniu wcale nie mniejszym przedmiotem historycznych studiów pozostaje bowiem nasza teraźniejszość, przy której - nie ogarnąwszy jej rozumieniem - wciąż jeszcze "nie czujemy się swobodnie”. Można by rzec: dziejopisarstwo wyrasta z przeczucia, że sprawy nam bliskie mają więcej niż jeden tylko wymiar, „związek, jedną prawdę, jedną wartość" ${ }^{\prime 39}$. Historyk pragnie rozświetlać to, co zapoznane w "tu i teraz".

Określając w dalszym ciągu warunki możliwości takiej nauki o dziejach, Humboldt podnosi „pierwotną zgodność pomiędzy podmiotem i przedmiotem". Czytamy:

Pojmowanie w żadnym razie nie jest wyłącznie rozwijaniem tego, co zawarte $\mathrm{w}$ podmiocie, ale też nie jest li tylko czerpaniem z przedmiotu, lecz jednym i drugim zarazem. Polega ono bowiem zawsze na stosowaniu tego, co ogólne i zawczasu obecne, do tego, co szczegółowe i nowe. Gdzie dwie istoty dzieli całkowita przepaść, tam nie połączy ich żaden most porozumienia, by się zaś porozumieć, trzeba się najpierw zrozumieć w in-

37 J. G. Droysen, Zarys historyki, op. cit., s. 18.

38 W. von Humboldt, O zadaniach dziejopisa, w: O myśli i mowie. Wybór pism z teorii poznania, filozofii dziejów i filozofii języka, oprac. E. M. Kowalska, PWN, Warszawa 2002, s. $28-49$.

39 Por. J. G. Droysen, Zarys historyki, op. cit., s. 17, 21. Tu, zdaje się, leży klucz do problemu "prawdy historycznej". 
nym sensie. W przypadku historii owa uprzednia podstawa pojmowania jest całkiem oczywista, cokolwiek bowiem wpływa na historię świata, powoduje także wnętrzem człowieka. Im głębiej przeto psychika narodu odczuwa wszystko, co ludzkie, im bardziej subtelnie, wszechstronnie i bezinteresownie ją to porusza, tym więcej naród ma predyspozycji do tego, by wydać historyków w prawdziwym sensie tego słowa ${ }^{40}$.

Oznacza to, że przybliżenie sobie przeszłego życia, które tutaj, najwyraźniej, jakoś łączy się z tym, co doświadczane również jako dziwnie bliskie i własne, zależy od umiejętności zachowania proporcji pomiędzy „wolnością" a „subtelną starannością" w jego oglądzie. Dziejopisarzowi nie wolno narzucać minionym wypadkom stworzonych arbitralnie pojęć - jak i, dodajmy, wobec własnej teraźniejszości poprzestać na utartym mniemaniu. Podwójnie wyzwoliwszy się z doktrynerstwa, musi on utrzymać w sobie "gotowość i wrażliwość", by domyślić się sił kierujących historią - sprężyny jej, formy ludzkiego czucia, myślenia, pragnień, leżą poza kręgiem bezpośredniej percepcji - aby im „pozostawić pole działania" ${ }^{41}$. Z drugiej strony - nie wolno mu zaniedbać w opisie tak zwanej „materialnej substancji”: niuansów tamtej konkretnej sytuacji, jej osobliwości, szczegółów. Krótko mówiąc: „Jeżeli historykowi brak wolności oglądu, nie pozna wydarzeń w całym ich zasięgu i głębi; gdy nie dostaje mu subtelnej staranności, uchybi ich prostej i żywej prawdzie"42.

Swoistością takiej historii jest wiele wiedzieć o materiale empirycznym, a oczami ducha ujmować możliwe, przeszłe i przyszłe, ludzkie uczucia, myśli, cele. Te ostatnie ukazywać na kanwie konkretnych faktów, ale też jako aktualne teraz i zawsze. Rozpinać łuk nad szeregiem osobnych zjawisk oraz indywidualnych charakterów z mniej i bardziej odległej rzeczywistości, by dać, pobudzający do filozoficznej refleksji, uniwersalny obraz losów ludzkich.

Dziejopisarstwo, skoro nie może obyć się bez sił wyobraźni, styka się też z wielkim systemem poezji. I nie ma to nic wspólnego z fałszowaniem przedmiotu, wymyślaniem samowolnie literackiej fikcji o przyczynach poruszających światem. Ponownie czytamy u Humboldta: „Spekulacja, doświadczenie i poetycka wyobraźnia nie są wszakże oddzielnymi, przeciwstawnymi lub ograniczającymi się nawzajem działaniami umysłu, lecz różnymi kierunkami promieniowania tej samej aktywności umysłowej" ${ }^{43}$. Charakter jej wyraża się w tworzeniu, jakbyśmy powiedzieli dziś, kompleksu symboli. Samowyzwalaniu się człowieka, który w budowie własnej idealnej przestrzeni dystansuje się od wszelkiej zewnętrzności. Duch ludzki „oswaja świat, przekształca go

\footnotetext{
40 W. Humboldt, op. cit., s. 40-41.

41 Ibidem, s. 49.

42 Ibidem.

${ }^{43}$ W. Humboldt, op. cit., s. 31.
} 
$\mathrm{w}$ ideę, urzeczywistnia tę ideę $\mathrm{w}$ tym samym świecie"44. Uobecnia się w uzewnętrznieniach historycznego życia oraz w tym, kto usiłuje je zrozumieć. Dziejopisarstwo chce opowiadać o tym nieustającym dążeniu pełnego wyobraźni ducha do urzeczywistnienia siebie w pracy symbolicznej, dla której tworzywem jest zmysłowa materia. Możliwość swą opiera na zrazu już istniejącym powiązaniu przedmiotu i poznającego. Odwołując się do całości tkwiących w nich umysłowych mocy - wzmagając w sobie potencjał symbolicznej imaginacji - historycy pogłębiają swoje rozumienie historycznych rzeczy i przybliżają się do prawdy ${ }^{45}$. W ten oto sposób Kantowski namysł nad rolą wyobraźni w ludzkim życiu został podjęty przez Humboldta i w pojęciach dynamicznych uległ dalszemu objaśnieniu. Jednak przeczucie, że problematyka ta wymagać będzie uwzględnienia kontekstu historii, pojawia się jeszcze u Kanta.

Czy Ja ludzkości, które Humboldt nauczył nas dostrzegać w dziejowych okolicznościach, starzeje się czy przeciwnie, staje młodsze z epoki na epokę, tego empirycznie nie umiemy poznać. Wiemy, że nie pozostaje takim, jakim było, mówił Droysen ${ }^{46}$. Ujmuje je następnie jako nieskończoną pracę, której pulsem jest podejmowany wciąż na nowo ruch wahadłowy pomiędzy ideą moralną w sumieniu lub sercu człowieka a doświadczaniem przez niego faktycznych stanów rzeczy; co oznacza - jako z natury wolność i wyobraźnię. Toczy się ona w życiu wspólnotowym celowo ukierunkowanym: rodzinie, związku terytorialnym i plemiennym, narodzie, państwie oraz w stowarzyszeniach duchowych, takich jak nauka, religia, sztuka i inne. Każda z tych wspólności ma swoją historię; obejmuje ona też ich wzajemne odniesienia. Materią owej pracy - czy, jak to określa uczony, jej „warunkiem i środkiem, zadaniem i przeszkodą"47 - jest to, co dane jako "przyroda” oraz sytuacje zaistniałe wskutek minionych wypadków. Sensem natomiast - samopoznanie człowieka i poprzez stałe pogłębianie oraz poszerzanie sfery doświadczeń jego budowanie siebie, dążenie ku „totalności”. Dlatego tak naprawdę wiedzą o dziejach człowieka są już same dzieje, powiada Droysen.

Zasadnicze nakierowanie na podnoszenie zastanej faktyczności do sfery moralnej (praca wspólnotowa) oznacza, że historyczna egzystencja przedstawia się człowiekowi nie w kategoriach ",atomów”, "punktów na linii", lecz dynamicznych złożonych wewnętrznych powiązań, ponieważ osiagnięcia poprzednich pokoleń traktuje on jako „bodziec i normę" w odniesieniu do twórczości własnej. Z drugiej strony - obecna

44 W. Humboldt, Lacjum a Hellada, czyli rozważania o starożytnosci klasycznej, op. cit., s. $86-87$.

45 W. Humboldt, O zadaniach dziejopisa, op. cit., s. 31.

46 J. G. Droysen, Zarys historyki, op. cit., s. 47.

47 Ibidem, op. cit., s. 39. 
własna celowa działalność nadaje w przypomnieniu określony kształt dotychczasowemu biegowi rzeczy. Wszelkie dokonanie należy zatem, materialnie i duchowo, tak do życia minionego, jak i teraźniejszości. Zajęcie postawy wobec współczesnego stanu spraw oznacza stanowisko względem przeszłości, w którym przejmujemy jej dzieje: problematy, osiągnięcia, porażki oraz samowiedzę. Wznosimy nasz mały intelektualny świat zawsze $w$ ramach i na gruncie skomplikowanego uniwersum samoświadomości, jaką przynosi praca dziejowo rozwijającej się ludzkości, gdzie: „każda z [...] komórek określana jest i podtrzymywana przez sąsiednie, które sama też określa i podtrzymuje. Wszystkie razem są jak jedna nieustannie rozrastająca się konstrukcja, podtrzymywana i określana przez byt najmniejszych części" ${ }^{48}$. Z tym z kolei łączy się ruchomość jego granic, ponieważ ustanawiając myślą powiązanie między przeszłością i przyszłością, gdy wspomina oraz czyni sobie nadzieje, człowiek stale poszerza ciasny horyzont swego „tu i teraz”. Podkreślmy na koniec aspekt tej sytuacji antropologicznej, istotny ze względu na możliwość obiektywnej historiografii, zagadnienia, w ramach którego w wywodach tych poruszamy się, orientując wedle punktu historycznej wyobraźni. Do teleologicznej struktury pracującego ludzkiego ducha należy, że choć pojęciową wizję siebie zawdzięcza nauce historycznej, od początku już istnieje na sposób „narracyjny”. W sformułowaniu Droysena brzmi to: „żyjemy i działamy na sposób praktyczny w ufnym odczuciu bytu naszego Ja, w bezpośrednim doznaniu totalności, w której się znajdujemy" ${ }^{\prime 9}$. Historyczne opowiadanie nie wnosi sensu i ciągłości w życie ducha z zewnątrz czy arbitralnie.

Przypominając wszystkie te zaszłości nie straciliśmy tymczasem z oczu naszego tematu. Pomiędzy światami Kanta, Humboldta, Droysena ukształtowała się inspirująca ontologiczna i antropologiczna optyka, która, twierdzimy, w odniesieniu do dziejów przejmuje Collingwood. Jej formułą na oddanie ludzkiej rzeczywistości był dualizm. Mówiąc z grubsza, życie historyczne miałoby tu niejako dwa oblicza: ontyczne i ontologiczne, faktyczne i faktualne ${ }^{50}$. Aby właściwie odnieść się do człowieka, ujmować go trzeba na dwóch planach: w konkretnej historycznej postaci, ale też od strony totalności „natury” ludzkiej, możliwości istnienia, jakie w sobie zawiera. Drugi z planów filozofowie i filozofujący dziejopisarze XIX wieku zwykli nazywać duchem. Referując węzłowe punkty, staraliśmy się ukazać, jak pogłębiało się jego rozumienie na linii prowadzącej od Kanta do Droysena.

Dokumenty przekazują nam słowa Nelsona, jakie wypowiedział podczas bitwy pod Trafalgarem. Dlaczego rozumiemy, co myślał

48 Ibidem, op. cit., s. 38.

49 Ibidem, s. 87.

50 Pojęć tych używamy w takim sensie, jaki nadał im w Byciu i czasie Heidegger. 
w chwili, kiedy je wygłaszał? Na czym polega to, że, mimo czasowego dystansu, odmienności życiowych doświadczeń, pojmujemy wewnętrzny sens pewnego zdarzenia z przeszłości - na przykład strategię Nelsona pod owym Trafalgarem? Albo problem nurtujący siedemnastowiecznego metafizyka, gdy umieszczał pewien zawiły passus w dziele? Albo cele, jakimi kierował się Juliusz Cezar, gdy przez dwa kolejne lata najeżdżał Brytanię? I w jaki sposób tamta motywacja oryginalna oraz jej rekonstrukcja w naszym umyśle, rzeczy niewątpliwie różne, pozostają jednym i tym samym zjawiskiem ${ }^{51}$

Zagadkę historycznego poznania Collingwood spodziewa się rozwiązać za pomocą koncepcji „,̇̇ywej historii" ${ }^{52}$. Totalności wiążącej, jeden z drugim, rozłączne momenty dziejowego przebiegu, odwołanie się do której - jako nośnika tamtych - czyni je dopiero zrozumiałymi. Tworzą ją pozostające w nieustannym ruchu „dzieje myśli." Ten heglowski termin informuje, że chodzi tu o świadomie stawiane dotąd przez ludzkość cele, projekty kreślone w różnych dziedzinach - polityce, gospodarowaniu, naukach, sztuce - które szczęśliwie znalazły trwały wyraz $\mathrm{w}$ postaci budowli kultury. A zatem - o uwieńczone pomyślnym rezultatem planowanie na podstawie wiedzy o rzeczywistości i wartościach. Interpretacja rozpoznaje jego ślad w strukturze rozległego świata duchowych wytworów, w jaki wplecione jest nasze subiektywne zmysłowo-duchowe istnienie. $W$ odniesieniach pomiędzy pewną jednostką a owym światem rozwija się z kolei jej ujęcie życia, wykształca postawa wobec niego, zarysowują nowe cele. $W$ spadku bierze ona również jego intelektualne i moralne przesłanki. Lecz przecież nie od razu zdaje sobie sprawę z tego, co odziedziczyła.

Przechodząc do epistemologicznych konsekwencji konceptu żywych „dziejów myśli”, Collingwood oświadcza:

[...] idea historii: idea imaginacyjnego obrazu przeszłości [...] jest, mówiąc po kartezjańsku, ideą wrodzona, a po kantowsku - a priori. Nie stanowi ona przypadkowego wyniku determinant psychologicznych; każdy człowiek nosi ją jako część wyposażenia swego umysłu. I jeśli tylko uprzytamnia sobie, co oznacza myśleć, natychmiast znajduje, że jest w jej posiadaniu. [...] Historyk [...] nigdy nie może uznać, że sposób, w jaki odmalował nam przeszłość, w najdrobniejszych szczegółach odpowiada jego idei o tym, czym w istocie była. Jednak, abstrahując od tego, jak fragmentaryczne i wciąż niedoskonałe jest jego naukowe osiagnięcie, idea, która mu przewodziła, pozostaje jasna, zrozumiała, uniwersalna. Jest ona

51 Pytania pochodzą z Autobiografii Collingwooda. Por. R. G. Collingwood, Autobiografia. Z dziejów mojego myślenia, Nomos, Kraków 2013.

52 R. G. Collingwood, Autobiografia. Z dziejów mojego myślenia, op. cit., ss. 96, 97, $110,138$. 
ideą historycznej wyobraźni jako samofundującej, samookreślającej się i samousprawiedliwiającej formy myśli ${ }^{53}$.

W ten sposób wszędzie tam, gdzie indywiduum spodziewa się ustanowić samodzielnie nowy początek, w teorii lub praktyce, określa je horyzont wspólnoty: historycznych światoobrazów, wykładni ogólnego sensu całości, wielorakich symbolicznych porządków, związków. Wszelki partykularny poznawczy horyzont stanowi konkretyzację ponadindywidualnych treści, jakie przynosi z sobą proces historyczny. Dla dziejopisarza sytuacja ta oznacza warunek historycznego rozumienia. Można to wyrazić i tak: w studiach nad przeszłościa, jednocześnie, prowadzi on samoobserwację. Albo: czerpie w nich z samowiedzy. To, co rekonstruuje, celowe działania, wynikłe z niegdysiejszych pojęć i życiowych postaw, sięga założeń wewnętrznego porządku instytucji współczesnego świata, osadziło się już w jego praktyce. W tym właśnie sensie Droysen mówił o "hipotetycznej linii”, jaką sam obiekt zainteresowań z góry nakreślił badaczowi. A więc ,"[...] wiedza historyczna może wyrosnąć jedynie z wiedzy historycznej; innymi słowy, historyczne myślenie stanowi pierwotną i fundamentalną aktywność umysłu" ${ }^{54}$. Uczony musi dysponować pewnym wstępnym pojęciem swego przedmiotu, aby prawidłowo postawić w stosunku do niego pytania. Ale też sposób ujęcia wyznacza mu sam przedmiot.

Wewnętrzne całościowe przedstawienie przeszłości, wskazane przez Collingwooda jako aprioryczna podstawa każdego konkretnego historycznego rozumienia, odznacza się dynamiką ${ }^{55}$. Gromadzimy dzięki niemu materiał w pewnej szczegółowej kwestii. Ten oświetlamy wszakże z nowych punktów widzenia, jakie w międzyczasie przyniósł rozwój naukowych technik, innych dyscyplin pokrewnych. W rezultacie dostrzegamy jej nieprzewidziane aspekty. Na powrót włączając ją teraz w nasze wyobrażenie dziejów, zmieniamy układ tworzących je treści. Zmodyfikowany poznawczy horyzont ukazuje nam z kolei nowy materiał. Historiografia nieustannie indukuje takie aktualizowanie imaginacji. W ten sposób sam jej warunek, aprioryczna idea historii, ewoluuje wraz z historią. Dla tej przyczyny dziejopisarstwo uważa, że przynosi ustalenia obiektywne, nigdy nie uznając żadnej swej pracy za naprawdę zakończoną.

Ujawnia się $\mathrm{w}$ tym stanowisku napięcie charakterystyczne dla wspomnianych wyżej antropologii historycznych. Jeśli rozpatrywać je na tle społeczno-kulturowego świata, w jakim występuje, empiryczne

53 R. G. Collingwood, The Idea of History, op. cit., s. 248, 249 (tłum. fragm. - I. S.).

54 Ibidem, s. 246.

55 W Autobiografii Collingwood wprowadza natomiast pojęcie „historii historii” w: R. G. Collingwood, Autobiografia, op. cit., s. 130. 
indywiduum pozostaje zewnętrznie określone przez takie, a nie inne „tu i teraz". Można jednak spojrzeć na tę sytuację z drugiej strony. Na jego stan posiadania składają się oto całe "dzieje myśli" - sfera, gdzie historyczny człowiek ukazuje się nam jako nieskończenie pomysłowy, wolny i twórczy. Historia znów nie sprowadza się do zmysłowej wielorakiej naoczności faktów, tego, co osobne, jednorazowe, szczególne, dla czego nie ma porównania. $W$ różnorodnych sektorach dziejowej empirii, przybierając odmienną postać z epoki na epokę, realizuje się planowe budowanie własnego świata przez człowieka historycznego; działanie, w którym także stopniowo uświadamia on sobie, do czego jest zdolny. Zmienna materia empirycznych dziejów odsyła zatem poza siebie ku pewnemu przejawiającemu się w niej "to samo", jakim jest moc planującej wyobraźni (świat myśli). Kwestia jest zbyt obszerna, więc musimy ją tylko zasygnalizować: podobnie jak tamte teorie ludzkiego istnienia historycznego, również Collingwood zmaga się w tym miejscu z problemem ontologicznym. To bowiem, co wydawało się „stałą" odkrytą w procesie przemian dziejów - myśl, ludzkie projektowanie twórcze znamy jedynie jako włączone w historyczną zmienność. Nie istnieje ponad płynną rzeczywistością empiryczną na gruncie pozahistorycznym. W jaki sposób pogodzić ze sobą te sprzeczności? Wyobraźnię, jaką zawsze jest człowiek historyczny, i jego zdeterminowanie przez przypadkowe dziejowe konstelacje?

Wydobywając z empirycznej historii jej ponadindywidualną osnowę - „dzieje myśli", czyli nieustanny ruch ludzkiej wyobraźni - Collingwood staje po stronie Humboldta i Droysena. Zagadnienie metodologiczne funkcji imaginacji $\mathrm{w}$ dziejopisarstwie, podobnie jak tam, zostało podjęte przez niego w szerszych ramach filozofii historii. To, że badacz, „,oczami ducha”, ogląda sytuacje z przeszłości, że potrafi odtworzyć czyjeś rozumowanie $z$ tamtych okoliczności, ma uzasadnienie ontologiczne - wynika to z jego uprzedniej przynależności do "dziejów myśli”. Potrzebne jest tu, być może, jedno zastrzeżenie. Czyni je Collingwood, ale jeszcze lepiej wyraził je Droysen:

bez względu na to, jak wielka jest pełnia tego, cośmy odziedziczyli i co przypada nam $\mathrm{w}$ udziale, wchodzimy $\mathrm{w}$ jego posiadanie dzięki własnej pracy, a to znaczy dzięki rozpoznaniu, że ów spadek jest tym, czym jest, właśnie jako efekt ustawicznej pracy tych, którzy byli przed nami. Kształceniem zwie się dorobek ducha, dorobek myśli, w historii epok i narodów, w dziejach ludzkości, przepracowany i przeżyty jako kontynuacja ${ }^{56}$.

Co prawdziwie składa się na intelektualny i moralny horyzont, jakim dysponujemy, tego bynajmniej nie uświadamiamy sobie od pierw-

56 J. G. Droysen, Zarys historyki, op. cit., s. 68. 
szej chwili. „Dzieje myśli” zatrzaśnięte są w powierzchniowym nurcie obecnego umysłowego życia jak w kapsule ${ }^{57}$. Dopiero posługująca się wyobraźnią historiografia budzi nasz „zmysł rzeczywistości” z dogmatycznej drzemki.

\section{Bibliografia}

Bloch M., Pochwała historii, czyli o zawodzie historyka, przeł. W. Jedlicka, oprac. H. Łaszkiewicz, przedmowa W. Kula, Wyd. Marek Derwiecki, Kęty 2009.

Collingwood R. G., Autobiografia. Z dziejów mojego myślenia, przeł. I. Szyroka, Nomos, Kraków 2013.

Collingwood R. G., The Idea of History, Oxford University Press 1948.

Droysen J. G., Zarys historyki, przeł. i oprac. M. Bonecki, J. Duraj, Oficyna Wydawnicza Epigram, Bydgoszcz 2012.

Heidegger M., Kant a problem metafizyki, przeł. i przedmową opatrzył B. Baran, Warszawa 1989.

Humboldt W. von, O myśli i mowie. Wybór pism z teorii poznania, filozofii dziejów i filozofii języka, oprac. E. M. Kowalska, PWN, Warszawa 2002.

Hudzik J. P., Koncepcja wyobraźni w filozofii Kanta, „Sztuka i Filozofia” 1994, nr 8, s. 93-122.

Juszczak W., Wędrówka do źródet, Gdańsk 2009.

Kant I., Transcendentalna dedukcja czystych pojęć intelektu (wyd. A), w: Krytyka czystego rozumu, przeł. R. Ingarden, BKF, PWN, Warszawa 1957.

Sauerland K., Od Diltheya do Adorna. Studia z estetyki niemieckiej, PIW, Warszawa 1986.

White H., Poetyka pisarstwa historycznego, red. E. Domańska i M. Wilczyński, Universitas, Kraków 2000.

\section{Streszczenie}

\section{Historia jako dzieło wyobraźni w The ldea of History R.G. Collingwooda}

Autorka zamierza tu wykazać, że to pomiędzy stanowiskami Kanta, Humboldta i Droysena ukształtowała się ontologiczna i antropologiczna optyka, jaką w odniesieniu do zagadnień historyki i dziejów przejmuje również Collingwood. Jej formułą na oddanie ludzkiej rzeczywistości był dualizm. Oznaczało to, że aby właściwie odnieść się do człowieka, ujmować go trzeba na dwóch planach: w konkretnej historycznej postaci, ale też od strony totalności „natury” ludzkiej,

57 R. G. Collingwood, Autobiografia, op. cit., s. 110-111. 
możliwości istnienia, jakie w sobie zawiera. Drugi z tych planów filozofowie i filozofujący dziejopisarze XIX wieku nazywali duchem. Referując węzłowe punkty, autorka szkicuje w artykule, jak pogłębiało się jego rozumienie na linii prowadzącej od Kanta do Droysena. Collingwood staje po stronie Humboldta i Droysena, kiedy metodologiczne zagadnienie roli imaginacji w dziejopisarstwie rozpatruje w szerszych ramach filozofii historii. I kiedy z empirycznej historii wydobywa jej ponadindywidualną osnowę - „dzieje myśli" jako nieustanny ruch ludzkiej wyobraźni. W uczestniczeniu przez historyka w tak rozumianych „żywych dziejach myśli” Collingwood znajduje ontologiczne uzasadnienie dla obiektywności posługującego się wyobraźnią oglądu przeszłości w historii.

Słowa kluczowe: antropologia, filozofia człowieka, historia, wyobraźnia historyczna, historiografia

\section{Summary}

\section{History as a Work of the Imagination in Robin G. Collingwood's The Idea of History}

In this article, I claim that the ontological and anthropological optics that shaped among the standpoints of Kant, Humboldt, and Droysen was also adopted by Collingwood in dealing with historical issues. Dualism was its mode of rendering human reality. This meant that a proper approach to man involved conceiving him on two tiers: in his concrete historical form, but also in terms of the totality of human "nature," or the possibilities of existence it includes. The second tier was commonly called "spirit" by the philosophers and philosophizing history writers of the nineteenth century. Referring to the cardinal points, the article sketches how its understanding grew deeper on the way from Kant to Droysen. Collingwood takes sides with Humboldt and Droysen, placing the methodological issue of the role of the imagination in history writing in the broader framework of the philosophy of history. He also does it by extracting a supra-individual structure from the empirical history - the "history of thought" as the constant movement of human imagination. Collingwood sees the historian's participation in this "living history of thought" as the ontological justification for the objectivity of the imaginative view of the past in history.

Keywords: anthropology, philosophy of man, history, historical imagination, historiography 